\title{
Suppressive effects of sodium fluoride on cultured splenic lymphocyte proliferation in mice
}

\author{
Ping Kuang ${ }^{1, *}$, Huidan Deng ${ }^{1, *}$, Hengmin Cui ${ }^{1,2}$, Lian Chen ${ }^{1}$, Hongrui Guo ${ }^{1}$, Jing \\ Fang ${ }^{1,2}$, Zhicai Zuo ${ }^{1,2}$, Junliang Deng ${ }^{1,2}$, Xun Wang ${ }^{1,2}$, Ling Zhao ${ }^{1,2}$ \\ ${ }^{1}$ College of Veterinary Medicine, Sichuan Agricultural University, Ya'an 625014, China \\ ${ }^{2}$ Key Laboratory of Animal Diseases and Environmental Hazards of Sichuan Province, Ya'an 625014, China \\ *These authors have contributed equally to this work \\ Correspondence to: Hengmin Cui, email: cui580420@sicau.edu.cn \\ Keywords: sodium fluoride, cytokine, cell cycle, splenic T lymphocytes, splenic B lymphocytes \\ Received: May 01, $2016 \quad$ Accepted: July 28, $2016 \quad$ Published: August 16, 2016
}

\section{ABSTRACT}

Fluoride-induced immunotoxicity has been documented in vivo, but limited reports have focused on the effects of fluoride on lymphocytes in vitro. Therefore, we have examined the suppressive effects of sodium fluoride on cultured splenic lymphocytes in mice. CD3+ T lymphocytes, CD19+ B lymphocytes, cytokines, and cell-cycle markers were analyzed through the use of a cell-counting kit, western blot, and flow cytometery. Splenic lymphocytes were isolated from 3-week-old male ICR mice and exposed to sodium fluoride $(0,100,500$, and $1000 \mu \mathrm{mol} / \mathrm{L})$ for $24 \mathrm{~h}$. The percentages of $\mathrm{CD}^{+}, \mathrm{CD}^{+} \mathrm{CD4}^{+}, \mathrm{CD}^{+} \mathrm{CD}^{+} \mathrm{T}^{+}$lymphocytes and $\mathrm{CD} 19^{+} \mathrm{B}$ lymphocytes were decreased $(P<0.05$ or $P<0.01)$ in the sodium fluoride-exposed cells. This finding was correlated with the alterations in expression levels of cytokine proteins and with evidence of cell-cycle arrest. Thus, protein expression levels of IL-2, TNF-a, IFN-y, TGF- $\beta$ were decreased $(P<0.05$ or $P<0.01)$, and IL-10 protein expression levels were increased $(P<0.05$ or $P<0.01)$. The percentage of lymphocyte in $G 1$ phase was significantly increased $(P<0.05$ or $P<0.01)$, while expression levels of cyclin $E / D$ and CDK2/4 were markedly decreased $(P<0.05$ or $P<0.01)$. These findings demonstrate that sodium fluoride exposure suppresses splenic lymphocyte proliferation, which is represented by reducing populations and activation of splenic $T$ and $B$ lymphocytes. Alterations of cytokine protein expression and cell cycle arrest are the molecular basis of the sodium fluoride-suppressed splenic lymphocyte proliferation, while reduction of T lymphocytes and B lymphocytes is the explanation of sodium fluoride-decreased splenic immune function in vitro.

\section{INTRODUCTION}

Fluorine is an essential trace element for human health. With growing importance of fluorinated chemicals, fluorine-containing drugs are used in medicine as anesthetics, antibiotics, anti-cancer and anti-inflammatory agents, psychopharmaceuticals, and in many other applications [1]. However, long-term excessive intake of sodium fluoride $(\mathrm{NaF})$ may result in serious skeletal and non-skeletal fluorosis [2-6] and dental fluorosis [7, 8]. Our previous studies documented fluorine-induced cytotoxicity, immunotoxicity, oxidative damage and pathological injury in the thymus [9], spleen [10-12], bursa of Fabricius [13], cecal tonsil [14-18], liver [19, 20], kidney [21-23], peripheral blood [24-27] and intestine [2832] of broiler chickens. Recently, sodium fluoride toxicity in cultured cells, including lymphocytes, has been reported [4, 33-39].

The immune system protects the body against infections, diseases and cancers. The spleen, a peripheral organ of the body's immune system, maintains immune homeostasis [40, 41], and $\mathrm{T}$ and $\mathrm{B}$ lymphocytes are its principal components of immune reactions. Alterations of splenic lymphocytes in response to fluoride exposure can reflect fluoride immunotoxicity [42]. Cytokines are immunoregulatory proteins that are important host 
mediators for response to stress, infection and other forms of antigen invasion [43]. Cell cycle is central to maintaining homeostasis in multicellular organisms [44], and loss of cell cycle control may lead to imbalances in cell proliferation and to cell death, which contribute to various disease states, including tumor formation [44]. A close relationship exists between fluoride and these various immune systems and functions. However, studies of possible fluoride toxicity in immunologic components have mostly been limited to studies on splenic T lymphocytes, interleukin-2 (IL-2) and interferon gamma (IFN- $\gamma$ ) in vivo and in vitro; no systematic studies have been reported on the effects of fluoride toxicity on splenic T and B lymphocytes, and analysis of cytokine and cyclin protein expression and cell-cycle alteration.

Therefore, this study was conducted to investigate $\mathrm{T}$ and $\mathrm{B}$ lymphocyte proliferation; alteration of $\mathrm{T}$ and $\mathrm{B}$ lymphocyte populations; changes of protein expression levels of cytokines, including IL-2, IL-10, IFN- $\gamma$, transforming growth factor beta (TGF- $\beta$ ) and tumor necrosis factor alpha (TNF- $\alpha)$; and cell-cycle arrest in cultured murine splenic lymphocytes. The results provide new understanding of the molecular mechanism of the cytotoxic effect of $\mathrm{NaF}$ on splenic lymphocytes and immune function of the cultured splenic lymphocytes.

\section{RESULTS}

\section{Half-maximal inhibitory concentration (IC50) of $\mathrm{NaF}$ on cultured splenic lymphocytes}

Figure 1 illustrated that the viability of splenic lymphocytes was decreased in response to increasing concentration of $\mathrm{NaF}$ at $24 \mathrm{~h}$. When the dose was over 1000 $\mu \mathrm{mol} / \mathrm{L}$, the cell activity was under $50 \%$. By calculating the IC50 in this study was $1000 \mu \mathrm{mol} / \mathrm{L}$. Based on IC50, doses of 100,500 , and $1000 \mu \mathrm{mol} / \mathrm{L} \mathrm{NaF}$ were chosen for study of lymphocyte proliferation.

\section{Effect of NaF treatment on proliferation of cultured splenic lymphocytes}

As illustrated in Figure 2A-2B, the proliferation of splenic B lymphocytes, stimulated with lipopolysaccharide, and of T lymphocytes, stimulated with concanavalin A, was decreased in a dose-dependent manner with increasing concentration of NaF. Lymphocyte proliferation was significantly lower in the middle-dose $(\mathrm{MG})(\mathrm{P}<0.05)$ and high-dose $(\mathrm{HG})(\mathrm{P}<0.01) \mathrm{NaF}$ groups than in the control group (CG).

\section{Effect of $\mathrm{NaF}$ treatment on cultured $\mathrm{CD3}^{+}$, $\mathrm{CD3}^{+} \mathrm{CD4}^{+}$, and $\mathrm{CD3}^{+} \mathrm{CD8}^{+}$splenic $\mathrm{T}$ lymphocytes and $\mathrm{CD}^{+}{ }^{+}$splenic B lymphocytes}

As illustrated in Figure 3A-3C, the percentages of $\mathrm{CD}^{+}, \mathrm{CD}^{+} \mathrm{CD}^{+}$, and $\mathrm{CD}^{+} \mathrm{CD}^{+} \mathrm{T}$ lymphocytes were significantly lower in the $\mathrm{MG}(\mathrm{P}<0.05)$ and $\mathrm{HG}(\mathrm{P}<0.01)$ than in the CG. Similarly, the percentages of CD19 ${ }^{+} \mathrm{B}$ lymphocytes were lower in the LG $(\mathrm{P}<0.05)$ and $\mathrm{MG}$ and $\mathrm{HG}(\mathrm{P}<0.01)$ than in the $\mathrm{CG}$ (Figure $3 \mathrm{D})$. However, there were no significant changes in the $\mathrm{CD} 4^{+} / \mathrm{CD}^{+}$ratios (Figure 3E).

\section{Effect of $\mathrm{NaF}$ treatment on cytokine protein expression in cultured splenic lymphocytes}

As shown in Figure 4A-4F, NaF decreased protein expression levels of IL-2, TGF- $\beta$, IFN- $\gamma$, and TNF- $\alpha$, and

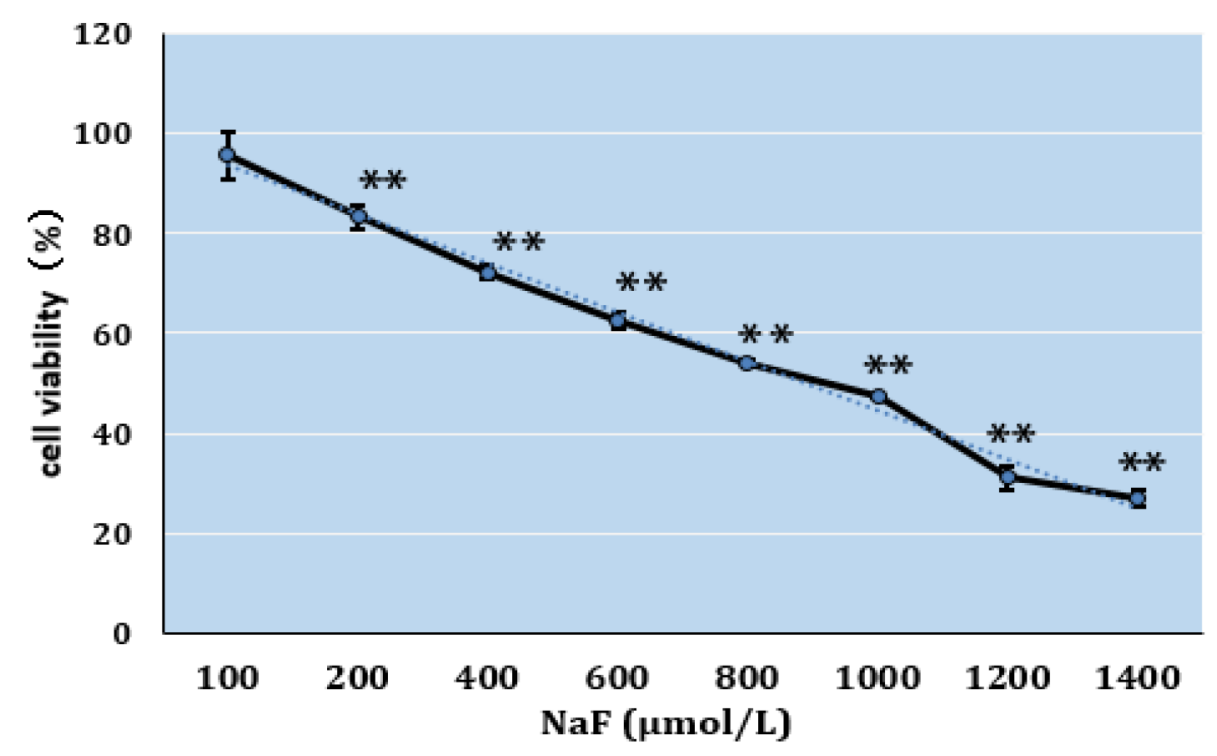

Figure 1: Cell viabilities of cultured splenic lymphocytes exposed to $\mathrm{NaF}$ at increasing concentrations as determined with cell counting kit-8. 
A

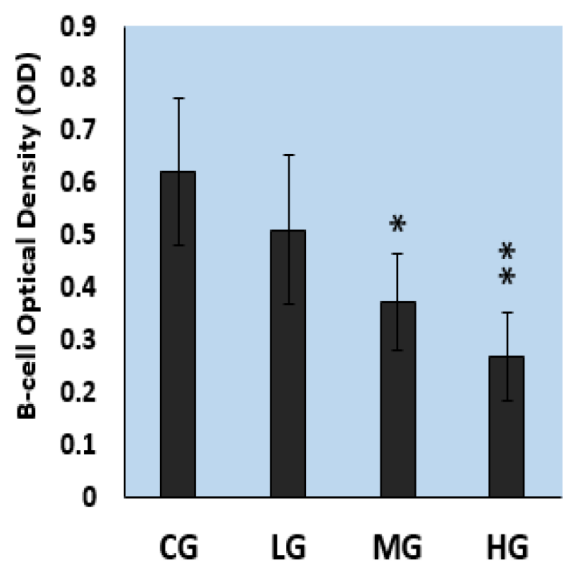

B

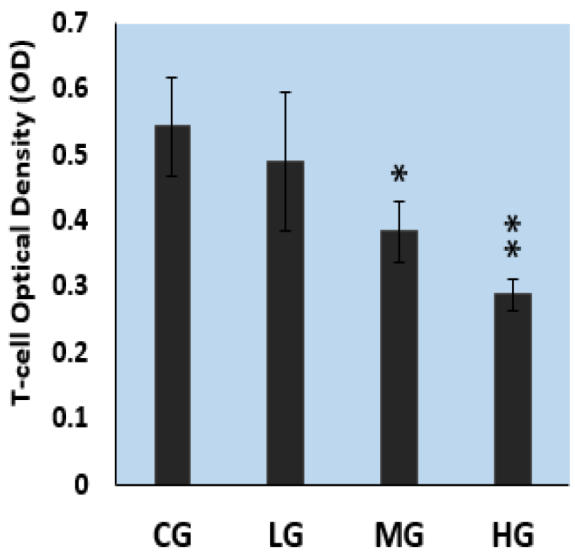

Figure 2: The effects of $\mathrm{NaF}$ on cell proliferation of splenic $\mathrm{T}$ and $\mathrm{B}$ lymphocytes as determined with cell counting kit-8. A. Splenic B lymphocyte proliferation by NaF combined with LPS stimulation. B. Splenic T lymphocyte proliferation by NaF combined with ConA stimulation. CG: control group, LG: low-dose NaF group, MG: middle-dose NaF group and HG: high-dose NaF group, LPS: Lipopolysaccharide, ConA: Concanavalin $\mathrm{A} * \mathrm{P}<0.05$, compared with the control group; $* * \mathrm{P}<0.01$, compared with the control group.
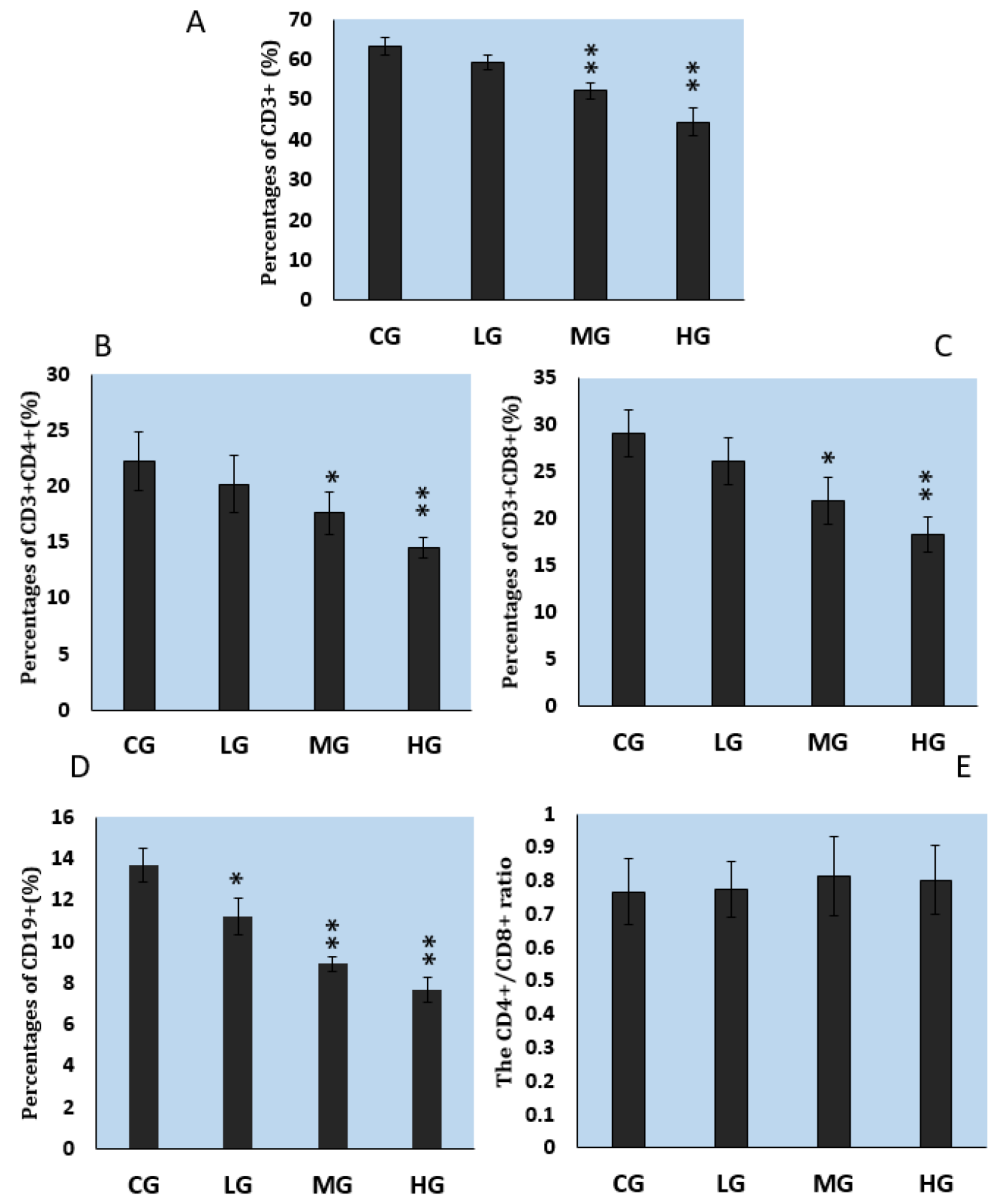

Figure 3: Changes of cultured splenic lymphocytes as determined with flow cytometry. A-C. $\mathrm{CD} 3^{+}, \mathrm{CD} 3^{+} \mathrm{CD} 4^{+}$, and $\mathrm{CD}^{+}{ }^{+} \mathrm{CD} 8^{+} \mathrm{T}$ lymphocyte percentages. D. CD19+ $\mathrm{B}$ lymphocyte percentages. E. $\mathrm{CD} 4^{+} / \mathrm{CD} 8^{+}$ratio. CG: control group, LG: low-dose $\mathrm{NaF}$ group, MG: middle-dose NaF group and HG: high-dose NaF group. ${ }^{*} \mathrm{P}<0.05$, compared with the control group; ** $\mathrm{P}<0.01$, compared with the control group. 
increased protein expression levels of IL-10 in cultured splenic lymphocytes.

\section{Effect of $\mathrm{NaF}$ treatment on cell cycle, and cyclins and cdks protein expression in cultured splenic lymphocytes}

As illustrated in Figure 5, NaF inhibited DNA synthesis of cultured splenic lymphocytes in a dosedependent manner. Figure 6 illustrates that $\mathrm{NaF}$ treatment, at $\mathrm{MG}$ and $\mathrm{HG}$, increased the cell percentage of cells in the G0G1 phase and decreased the percentage in the $\mathrm{S}$ and G2M phases.

To reveal the mechanism of NaF-arrested G1 phase of the cell cycle, we determined expression levels of the G1 phase-related regulatory molecules, cyclins and cdks, with western blot. As illustrated in Figure 7A-7D, NaF treatment at the high dose $(\mathrm{HG})$ significantly $(\mathrm{P}<0.01)$ decreased the protein levels of CDK2 and CDK4 but had no effect on CDK1. In Figure 8A-8E, it can be seen

\section{B}

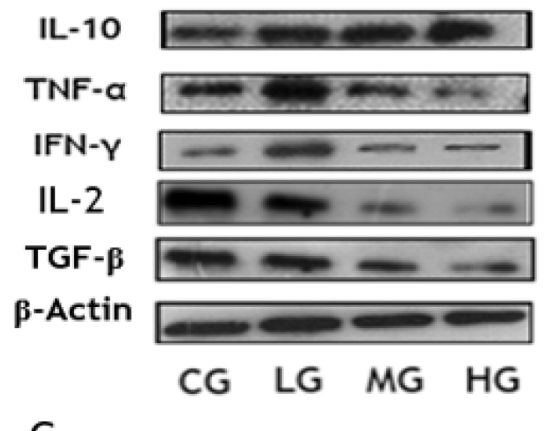

C
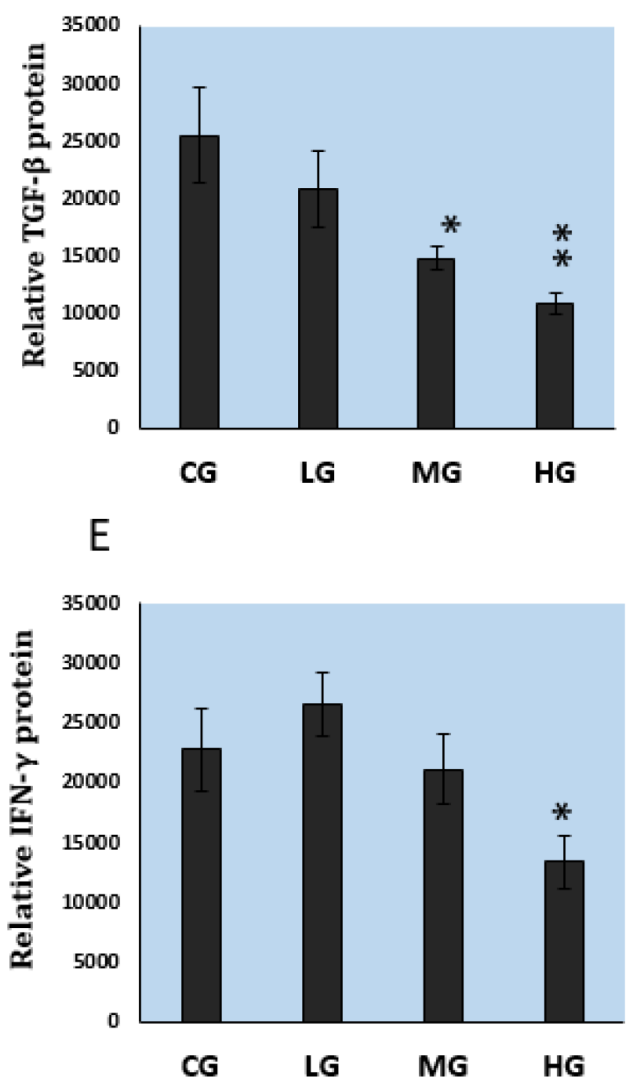
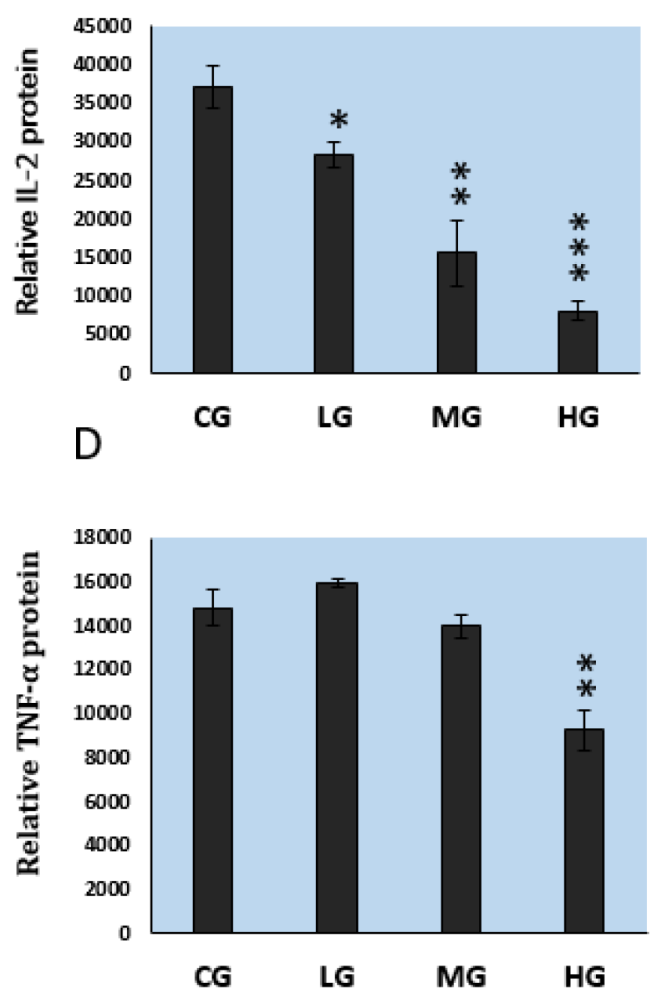

$\mathrm{F}$

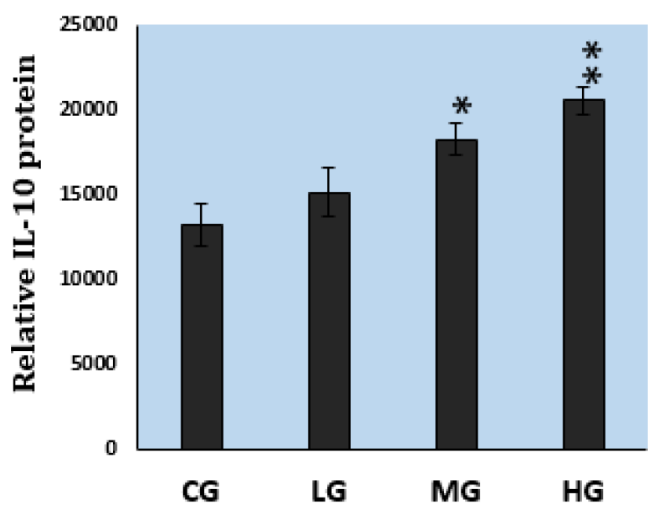

Figure 4: Protein expression levels of cytokines in cultured splenic lymphocytes A. Western blot assay. B-F. Quantitative measurement of the relative protein expression of IL-2, TGF- $\beta$, TNF- $\alpha$, IFN- $\gamma$, and IL-10 CG: control group, LG: low-dose NaF group, $\mathrm{MG}$ : middle-dose $\mathrm{NaF}$ group and $\mathrm{HG}$ : high-dose $\mathrm{NaF}$ group. ${ }^{*} \mathrm{P}<0.05$, compared with the control group; $* * \mathrm{P}<0.01$, compared with the control group. 
that $\mathrm{NaF}$ treatment at the $\mathrm{MG}$ and $\mathrm{HG}$ concentrations significantly decreased cyclins $\mathrm{D}$ and $\mathrm{E}(\mathrm{P}<0.05-\mathrm{P}<0.01)$, whereas it had no effect on cyclins $\mathrm{A}$ and $\mathrm{B}(\mathrm{P}>0.05)$.

\section{DISCUSSION}

There are no systematic studies on the effects of fluoride toxicity on splenic $\mathrm{T}$ and $\mathrm{B}$ lymphocytes, and analysis of cytokine and cyclin protein expression and cell-cycle alteration at present. Thus, this study focused on the cultured splenic lymphocyte proliferation at $24 \mathrm{~h}$, and aimed to provide new experimental evidences for understanding the molecular mechanism of $\mathrm{NaF}$ cytotoxicity in the future studies. Indeed, we found in this in vitro study that $\mathrm{NaF}$ suppressed the proliferation of cultured splenic lymphocyte by reducing $\mathrm{T}$ and $\mathrm{B}$ lymphocyte populations and viability (Figure 1,2); altering protein expression of cytokines IL-2, IL-10, IFN- $\gamma$, TGF- $\beta$ and TNF- $\alpha$; and arresting the cell cycle. It is firstly observed that $\mathrm{NaF}$ reduces splenic $\mathrm{B}$ lymphocytes and alters splenic lymphocyte TGF- $\beta$ and IL-10 protein expression in vitro, and arrests splenic lymphocyte cell cycle in vitro.

Splenic lymphocytes play very important roles in body's immune response, which are mainly involved in cellular immunity and humoral immunity [40]. Thus,

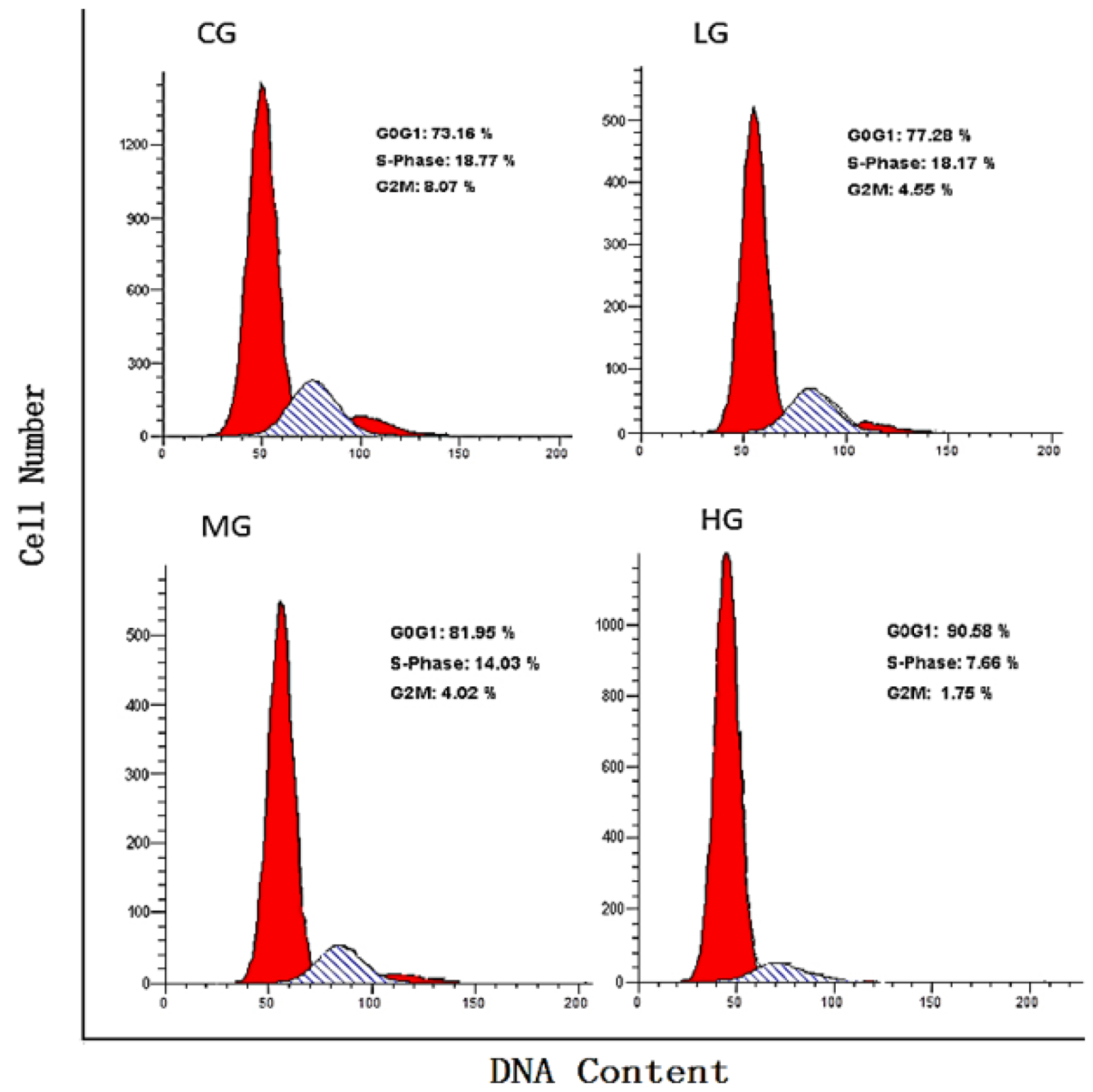

Figure 5: Effects of $\mathrm{NaF}$ on the DNA content of splenic cells in various phases of the cell cycle, as measured with flow cytometry. CG: control group, LG: low-dose NaF group, MG: middle-dose NaF group and HG: high-dose NaF group. 
in this study, we chose splenic T and B lymphocytes for evaluation of the immune status of mice after $\mathrm{NaF}$ exposure. Treatment with $\mathrm{NaF}$ directly decreased the proliferation of splenic $\mathrm{T}$ and $\mathrm{B}$ lymphocytes--CD3 ${ }^{+} \mathrm{T}$ lymphocytes, $\mathrm{CD}^{+} \mathrm{CD}^{+} \mathrm{T}$ lymphocytes, $\mathrm{CD}^{+} \mathrm{CD} 8^{+}$ $\mathrm{T}$ lymphocytes and $\mathrm{CD} 19^{+} \mathrm{B}$ lymphocytes (Figure 3 ). This finding is consistent with the results of Liu et al $[15,16]$, and Luo et al [29], who found that dietary high fluorine reduced the numbers of $\mathrm{T}$ lymphocytes and $\mathrm{B}$ lymphocytes in the cecal tonsil, and B lymphocytes in the intestinal mucous [32] of broiler chickens. Also, Peng et al.[38] has reported that fluorine ion decreases cultured splenic $\mathrm{CD}^{+} \mathrm{T}$ lymphocytes of male Kunming mice in vitro. Accordingly, the reduction of $\mathrm{T}$ lymphocytes and $\mathrm{B}$ lymphocytes seems to account for $\mathrm{NaF}$-decreased splenic immune function.

Cytokines are critical regulators of the immune system by activating and modulating the function of immune cells [45]. Thus, there is a close relationship between lymphocytes and cytokines in the spleen. In this in vitro study, $\mathrm{NaF}$ altered the protein expressions of IL-2, TNF- $\alpha$, IFN- $\gamma$, IL-10 and TGF- $\beta$ in cultured splenic lymphocytes (Figure 4). IL-2, TNF- $\alpha$, and IFN- $\gamma$ are crucial cytokines in the regulation of immune function, through enhanced cell-mediated immunity. In this study, protein expression levels of IL-2, TNF- $\alpha$, and IFN- $\gamma$ were decreased (Figure 4B, 4D, 4E) by $\mathrm{NaF}$, indicating that $\mathrm{NaF}$ could reduce the population of $\mathrm{T}$ lymphocytes and likely result

A

B
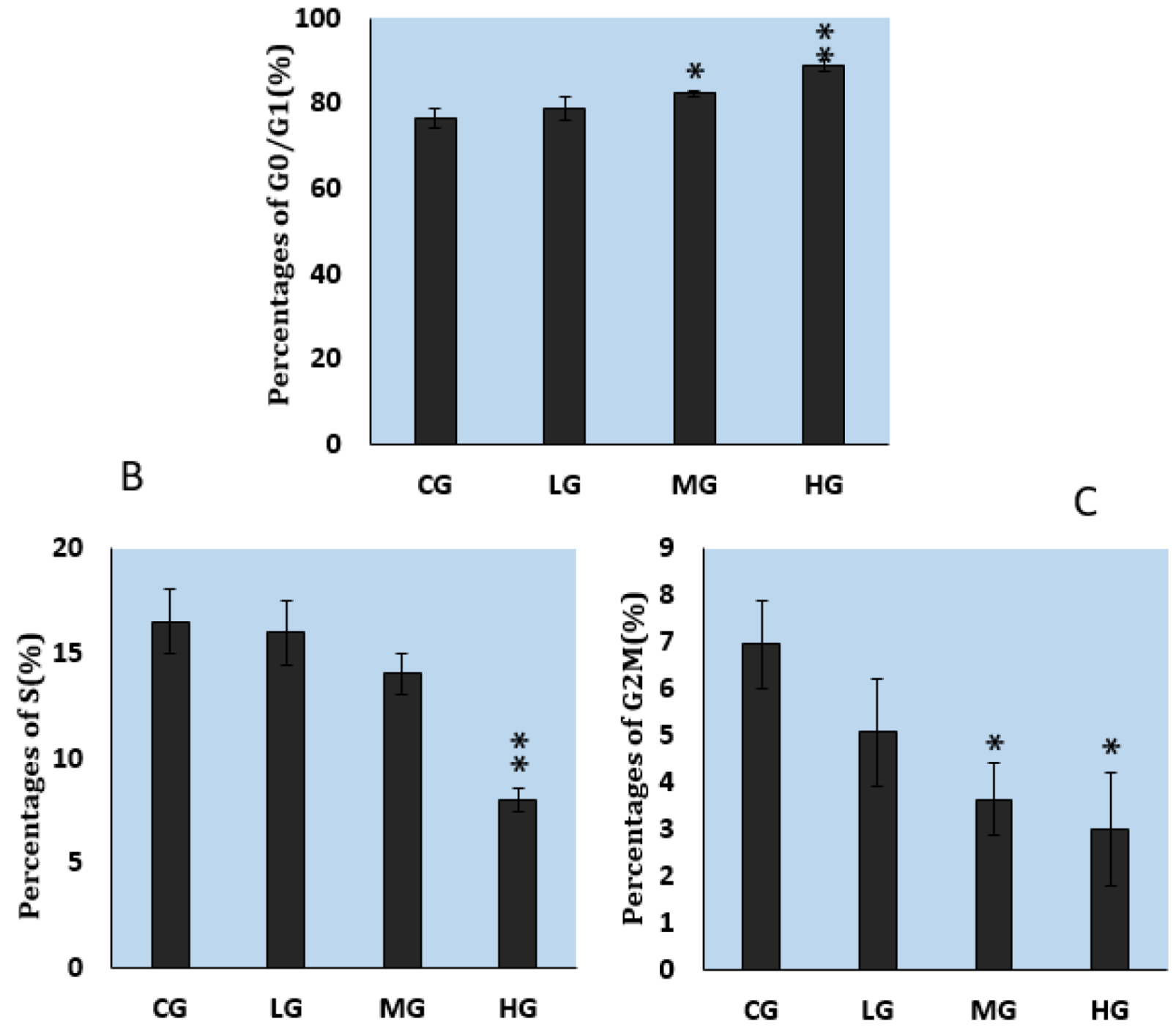

Figure 6: Effects of $\mathrm{NaF}$ on percentages of cultured splenic lymphocytes in various stages of the cell cycle, as measured with flow cytometry. A. G0/G1 phase. B. S phase. C. G2M phase. CG: control group, LG: low-dose NaF group, MG: middle-dose NaF group and HG: high-dose $\mathrm{NaF}$ group. ${ }^{*} \mathrm{P}<0.05$, compared with the control group; $* * \mathrm{P}<0.01$, compared with the control group. 
in impaired cell-mediated immune function. The reduction of IL- 2, TNF- $\alpha$ and IFN- $\gamma$ expression was consistent with previous reports in cecal tonsil and intestine of broiler chickens fed high fluoride diets [19, 35]. Also, IL-2 mRNA expression levels have been reduced in cultured splenic $\mathrm{T}$ lymphocyte in the presence of $\mathrm{NaF}$ [39].

IL-10 and TGF- $\beta$ are inhibitory cytokines, synthesized by $\mathrm{T}$ cells and $\mathrm{B}$ cells [46], and IL-10 combined with TGF- $\beta$ can promote the production of IgA [47]. To our knowledge, there have been no reports on NaF-altered IL-10 and TGF- $\beta$ protein expression in splenic lymphocyte in vivo or in vitro. In this study, TGF- $\beta$ protein expression levels were decreased and IL-10 protein expression levels were increased in $\mathrm{NaF}$-treated cells (Figure 4C, 4F). The alteration of these expression levels indicates that $\mathrm{NaF}$ exposure reduces populations of T lymphocytes and B lymphocytes, which further impacts splenic immune function in mice.

The suppression of splenic lymphocyte proliferation is closely correlated with the cell cycle in addition to the relationship between suppression of splenic lymphocyte proliferation and cytokines. Our results showed that $\mathrm{NaF}$ caused $\mathrm{G} 1$ phase cell-cycle arrest (Figure 5-6), a result that is consistent with reports on fluoride-induced increases in the proportion of cells in the G0/G1 phase in the spleen $[12,48]$. Progression from $\mathrm{G} 1$ to $\mathrm{S}$ phase of the mammalian cell cycle is regulated by cyclin D-dependent kinases, including Cdk4 and Cdk6, binding to D-type cyclins, and by Cdk2 binding to cyclins $\mathrm{E}$ or $\mathrm{A}[49,50]$. In order to define $\mathrm{NaF}$-induced G1 phase cell-cycle arrest in the cultured splenic lymphocytes, we measured cell-cycle regulatory proteins. We found that protein expression levels of cyclin E, cyclin D, CDK2 and CDK4 were significantly reduced in the MG and $\mathrm{HG}$ (Figure 7C-7D; Figure 8B$8 \mathrm{C}$ ), while protein expression levels of cyclin B, cyclin A, and CDK1 were not changed. Ngoc et al.[51] have reported that $\mathrm{NaF}$ can reduce cyclin $\mathrm{E}$ levels in mouse embryonic stem cells, indicating that $\mathrm{NaF}$ treatment slows the G1 process and blocks the G1/S transition.
A

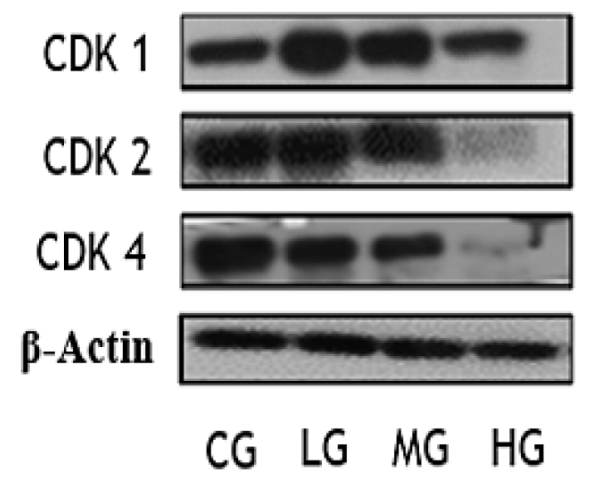

C

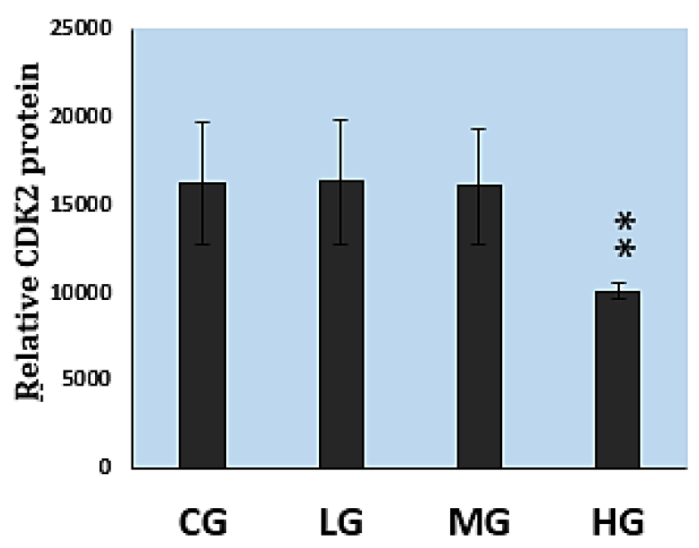

B
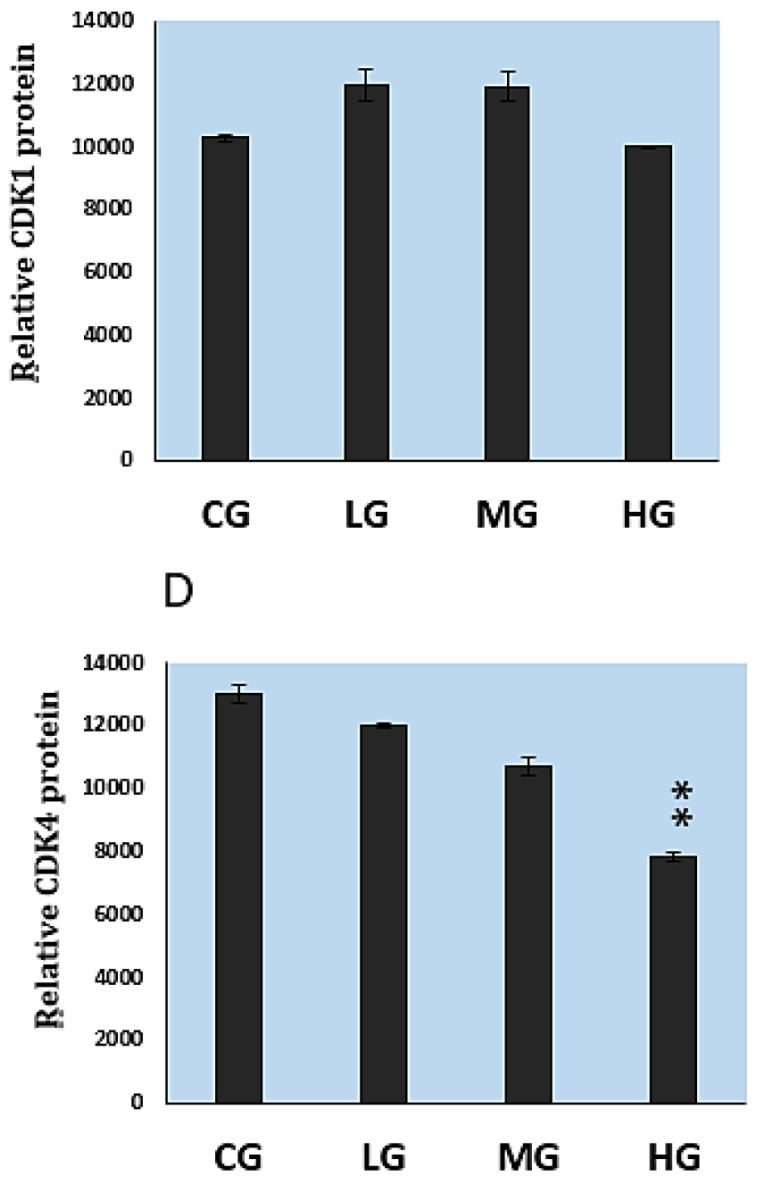

Figure 7: Protein expression levels of cyclin-dependent kinases in cultured splenic lymphocytes, as determined with quantitative measurement of western blots A. Western blot assay. B-D. Quantitative analysis of CDKs relative protein expression. CG: control group, LG: low-dose NaF group, MG: middle-dose NaF group and HG: high-dose NaF group. ${ }^{*} \mathrm{P}<0.05$, compared with the control group; $* * \mathrm{P}<0.01$, compared with the control group. 


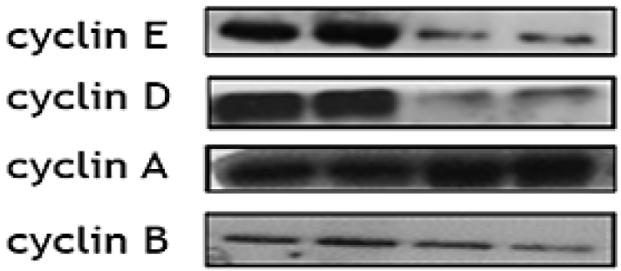

p-Actin

B

CG LG MG HG

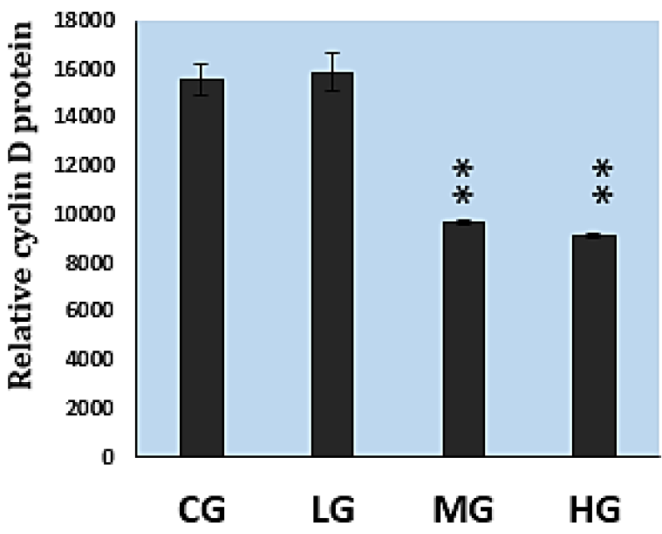

D
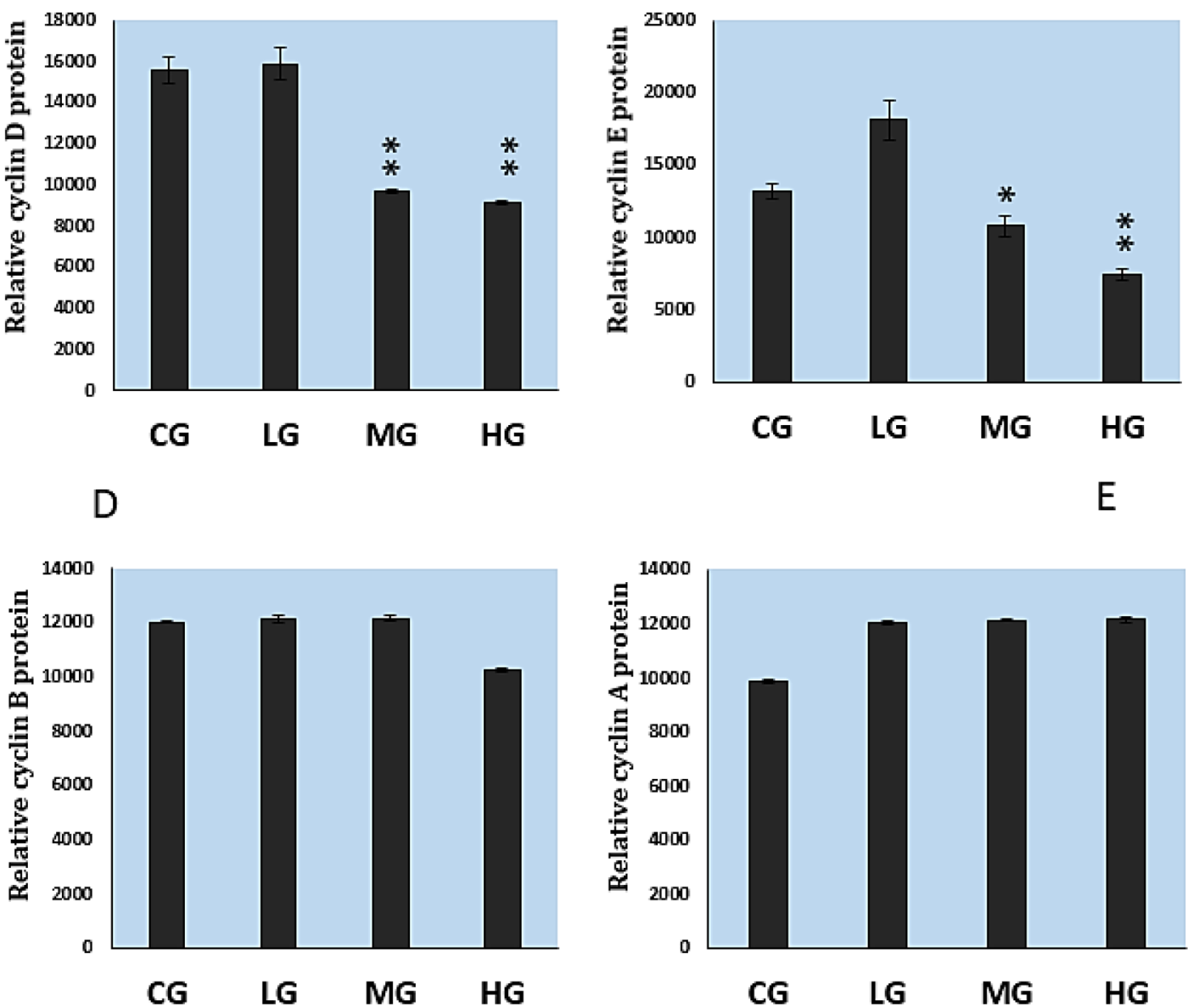

Figure 8: Cyclins expression in cultured splenic lymphocytes as determined with western blot and quantitative measurement A. Western blot show. B-E. Quantitative analysis of cyclins relative protein expression. CG: control group , LG: lowdose NaF group, $\mathrm{MG}$ : middle-dose $\mathrm{NaF}$ group and $\mathrm{HG}$ : high-dose $\mathrm{NaF}$ group. ${ }^{*} \mathrm{P}<0.05$, compared with the control group; ${ }^{* *} \mathrm{P}<0.01$, compared with the control group.

We conclude that $\mathrm{NaF}$ in the $500,1000 \mu \mathrm{mol} / \mathrm{L}$ suppresses cultured lymphocyte proliferation, which is represented by reducing population and activation of splenic $\mathrm{T}$ and $\mathrm{B}$ lymphocytes. Cytokine protein expression alteration and cell cycle arrest are the molecular basis of $\mathrm{NaF}$-suppressed splenic lymphocyte proliferation. Also, we believe this in vitro study is the first to show sodium fluoride-decreased splenic immune function by reducing not only T lymphocytes, but also B lymphocytes.

\section{MATERIALS AND METHODS}

\section{Animals}

Three-week-old healthy male ICR mice were provided by the Experimental Animal Corporation of DOSSY at Chengdu, China.

Our experiments involving the use of mice and all experimental procedures were approved by the 
Animal Care and Use Committee, Sichuan Agricultural University.

\section{Lymphocyte isolation, culture and treatment}

Mice were anesthetized and euthanized, then soaked in $75 \%$ ethanol for 3 to $5 \mathrm{~min}$. The spleens were removed at laparotomy, washed with cold phosphatebuffered saline (PBS, pH 7.4), and placed in a 200mesh stain steel sieve over a culture dish containing 4-5 $\mathrm{mL}$ lymphocyte isolation separation medium. The spleens were ground into small pieces with the plunger of glass syringe. The liquid was transferred into a centrifuge tube and overlaid onto a layer of 200-500 $\mu \mathrm{L}$ RPMI-1640 and centrifuged at $800 \times \mathrm{g}$ for $30 \mathrm{~min}$ at room temperature, with three layers were formed. The middle, milky layer containing lymphocytes was transferred into a test tube. The lymphocytes were washed twice with PBS and suspended in RPMI-1640 medium with $10 \%$ fetal calf serum and transferred into a culture bottle. The mentioned procedures were performed under sterile condition. The viability of the lymphocyte was estimated according to trypan blue exclusion criteria.

To analyze $\mathrm{T}$ and $\mathrm{B}$ lymphocytes, lymphocyte proliferation, cytokines, cell cycle by cell counting Kit- 8 (CCK-8, Beyotime, Jiangsu, China), western blot and flow cytometry. The splenic lymphocytes were cultured in the RPMI-1640 medium (supplemented with 10\% fetal calf serum, $100 \mu / \mathrm{mL}$ penicillin, and $100 \mu \mathrm{g} / \mathrm{mL}$ streptomycin), containing 0 (control group ,CG), 100((low-dose group, LG), 500 (medial-dose group, MG), and 1000 (high-dose group, $\mathrm{HG}) \mu \mathrm{mol} / \mathrm{L} \mathrm{NaF}$. Experiments were repeated in treplicate. The cells were maintained in a humidified incubator for $24 \mathrm{~h}$ at $37^{\circ} \mathrm{C}$ with $5 \% \mathrm{CO} 2$.

\section{Cell viability assay}

$1 \times 10^{5}$ splenic lymphocytes were seeded in 96-well cell culture plates and were exposed to $\operatorname{NaF}(0,100,200$, $400,600,800,1000,1200,1400 \mu \mathrm{mol} / \mathrm{L}$ ) for $24 \mathrm{~h}$ with $5 \% \mathrm{CO}_{2}$. The cells were then incubated with $10 \mu \mathrm{L} \mathrm{CCK}-8$ agents (Beyotime, Jiangsu, China) in $100 \mu \mathrm{L}$ medium for $4 \mathrm{~h}$ at $37^{\circ} \mathrm{C}$. The optical density (OD) was measured by using the Thermo Scientific ${ }^{\mathrm{TM}}$ M $\mu$ Ltiskan microplate spectrophotometer (Thermo Fisher Scientific; Waltham, MA, USA) at a wavelength of $450 \mathrm{~nm}$.

\section{Cell proliferation assay}

Splenic lymphocytes were seeded into 96-well cell culture plates $\left(1 \times 10^{5} /\right.$ well $)$ and exposed to $\mathrm{NaF}(0,100$, 500 , and $1000 \mu \mathrm{mol} / \mathrm{L}$ ), and lipopolysaccharide (LPS, 10 $\mu \mathrm{g} / \mathrm{mL}$ ) or concanavalin A (ConA, $5 \mathrm{ug} / \mathrm{mL}$ ) was added. The cells were incubated at $37^{\circ} \mathrm{C}$ under $5 \% \mathrm{CO}_{2}$ for $24 \mathrm{~h}$. At the indicated time points, $10 \mu \mathrm{L}$ CCK- 8 solution was added to each well, and the plates were incubated for $4 \mathrm{~h}$. The optical density (OD) was measured at $450 \mathrm{~nm}$.

\section{Protein expression analysis by western blot}

Cells were lysed, and proteins were extracted with RIPA lysis buffer and kept in Laemmli buffer. Protein samples were resolved on SDS-PAGE $(10 \%-15 \%$ gels) and transferred to nitrocellulose filter membranes. Membranes were blocked with 5\% fat-free milk for $1 \mathrm{~h}$ and incubated with primary antibodies overnight at $4{ }^{\circ} \mathrm{C}$. The primary antibodies were cyclin $\mathrm{D} / \mathrm{E} / \mathrm{B} / \mathrm{A}, \mathrm{CDK} 1 / 2 / 4$ (Abcam, UK) and TNF- $\alpha$, IFN- $\gamma$, TGF- $\beta$, and IL-2, IL10 (Santa Cruz, USA). The membranes were then washed with PBS-tween and incubated with biotin-conjugated secondary antibodies (Santa cruz, USA) for $1 \mathrm{~h}$, and washed again with PBS-tween. Blots were visualized by $\mathrm{ECL}^{\mathrm{TM}}$ (Bio-Rad, Hercules, CA, USA) and X-ray film.

\section{Lymphocyte and cell cycle analysis by flow cytometer}

The percentages of cultured splenic lymphocyte subsets were measured by flow cytometer, using monoclonal fluorescein isothiocyanate (FITC) antimouse $\mathrm{CD}^{+}$, phycoerythrin (PE) anti-mouse $\mathrm{CD}^{+}$, PerCp anti-mouse $\mathrm{CD} 8^{+}$and FITC anti-mouse $\mathrm{CD} 19^{+}$ (BD Biosciences, San Jose, CA, USA) as monoclonal antibodies labeled, respectively. The results were analyzed using the Cell Quest computer program.

The cell cycle was measured by flow cytometer. Cells were incubated for $30 \mathrm{~min}$ at room temperature in the dark with $0.15 \%$ Triton X-100 and propidium iodide (PI). The results were analyzed by the use of the Mod Fit LT for Mac V3.0 computer program.

\section{Statistical analysis}

Data were expressed as mean \pm standard deviation (SD). One-way analysis of variance (ANOVA) procedure in SPSS 17.0 software was used to assess statistical significances between F-treated group and control group. A value of $\mathrm{P}<0.05$ was considered significant, and $\mathrm{P}<0.01$ was markedly significant.

\section{ACKNOWLEDGMENTS}

The study was supported by the program for Changjiang scholars and innovative research team in university (IRT 0848) and the Shuangzhi project of Sichuan Agricultural University (03570327; 03571198).

\section{CONFLICTS OF INTEREST}

The authors declare no conflict of interest. 


\section{REFERENCES}

1. Strunecka A, Patocka J and Connett P. Fluorine in medicine. J Appl Biomed. 2004; 2:141-150.

2. Fordyce F, Vrana K, Zhovinsky E, Povoroznuk V, Toth G, Hope B, Iljinsky U and Baker J. A health risk assessment for fluoride in Central Europe. Environmental geochemistry and health. 2007; 29:83-102.

3. Patra R, Dwivedi S, Bhardwaj B and Swarup D. Industrial fluorosis in cattle and buffalo around Udaipur, India. Science of the Total Environment. 2000; 253:145-150.

4. Liu H, Sun J, Zhao Z, Zhang J, Xu H and Li G. Fluorideinduced oxidative stress in three-dimensional culture of OS732 cells and rats. Biological trace element research. 2011; 143:446-456.

5. Basha PM, Rai P and Begum S. Evaluation of fluorideinduced oxidative stress in rat brain: a multigeneration study. Biological trace element research. 2011; 142:623-637.

6. Basha PM and Sujitha N. Combined influence of intermittent exercise and temperature stress on the modulation of fluoride toxicity. Biological trace element research. 2012; 148:69-75.

7. Błaszczyk I, Birkner E, Gutowska I, Romuk E and Chlubek D. Influence of methionine and vitamin $\mathrm{E}$ on fluoride concentration in bones and teeth of rats exposed to sodium fluoride in drinking water. Biological trace element research. 2012; 146:335-339.

8. Ba Y, Zhang H, Wang G, Wen S, Yang Y, Zhu J, Ren L, Yang R, Zhu C and Li H. Association of dental fluorosis with polymorphisms of estrogen receptor gene in Chinese children. Biological trace element research. 2011; 143:87-96.

9. Chen T, Cui H, Cui Y, Bai C, Gong T and Peng X. Cellcycle blockage associated with increased apoptotic cells in the thymus of chickens fed on diets high in fluorine. Human \& experimental toxicology. 2011; 30:685-692.

10. Chen T, Cui H, Cui Y, Bai C and Gong T. Decreased antioxidase activities and oxidative stress in the spleen of chickens fed on high-fluorine diets. Human \& experimental toxicology. 2011; 30:1282-1286.

11. Chen T, Cui Y, Bai C, Gong T, Peng X and Cui H. Increased apoptotic lymphocyte population in the spleen of young chickens fed diets high in fluorine. Fluoride. 2009; 42:94.

12. Chen T, Cui Y, Gong T, Bai C, Peng X and Cui H. Inhibition of splenocyte proliferation and spleen growth in young chickens fed high fluoride diets. Fluoride. 2009; 42:203.

13. Chen T, Gong T, Bai C, Peng X and Cui H. Effect of dietary high fluorine on the morphologic structure, cell cycle and apoptosis of bursa of fabricius in broilers. Chinese Journal of Animal and Veterinary Sciences. 2009; 8:021.

14. Liu J, Cui H, Peng X, Fang J, Zuo Z, Wang H, Wu B, Deng $\mathrm{Y}$ and Wang K. Changes induced by high dietary fluorine in the cecal tonsil cytokine content of broilers. Fluoride. 2012; 45:102-106.

15. Liu J, Cui H, Peng X, Fang J, Zuo Z, Deng J, Wang H, Wu B, Deng Y and Wang K. Decreased IgA+ B cells population and IgA, IgG, IgM contents of the cecal tonsil induced by dietary high fluorine in broilers. International journal of environmental research and public health. 2013; 10:1775-1785.

16. Liu J, Cui H, Peng X, Fang J, Zuo Z, Wang H, Wu B, Deng $\mathrm{Y}$ and Wang K. Decreased percentages of T-cell subsets and IL-2 contents in the cecal tonsil of broilers fed diets high in fluorine. Fluoride. 2012; 45:53-57.

17. Liu J, Cui H, Peng X, Fang J, Zuo Z, Wang H, Wu B, Deng $\mathrm{Y}$ and Wang K. Dietary high fluorine induces apoptosis and alters bcl-2, bax, and caspase-3 protein expression in the cecal tonsil lymphocytes of broilers. Biological trace element research. 2013; 152:25-30.

18. Liu J, Cui H, Peng X, Fang J, Zuo Z, Wang H, Wu B, Deng $\mathrm{Y}$ and Wang K. High dietary fluorine induction of oxidative damage in the cecal tonsil of broilers. Fluoride. 2012; 45:47.

19. Gong T, Chen T, Bai C, Peng X and Cui H. Effect of dietary high fluorine on the cell cycle and apoptosis of liver in chickens. Chinese Journal of Animal and Veterinary Sciences. 2009; 11:015.

20. Gong T, Bai C, Chen T, Peng X and Cui H. Effect of high fluorine on the antioxidant function and ultrastructure of liver in chickens. Chinese Journal of Animal and Veterinary Sciences. 2009; 9:016.

21. Bai C, Chen T, Cui Y, Gong T, Peng X and Cui H. Effect of high fluorine on the cell cycle and apoptosis of renal cells in chickens. Biological trace element research. 2010; 138:173-180.

22. Bai C, Chen T, Gong T, Peng X and Cui H. Pathological effect of high fluorine on kidney and the related biochemical paramelers of serum in the chicken. Chinese Journal of Veterinary Science. 2010; 4:019.

23. Bai C, Peng X, Gong T, Chen T and Cui H. Effect of high fluorine on the antioxygen function of kidney in chickens. Chinese Journal of Veterinary Science. 2010; 30:825-828.

24. Chen T, Cui Y, Bai C, Gong T, Peng X and Cui H. Decreased percentages of the peripheral blood T-cell subsets and the serum IL-2 contents in chickens fed on diets excess in fluorine. Biological trace element research. 2009; 132:122-128.

25. Deng Y, Cui H, Peng X, Fang J, Zuo Z, Deng J and Luo Q. Effects of high dietary fluoride on serum biochemistry and oxidative stress parameters in broiler chickens. Health. 2014; 6:1840-1848.

26. Deng Y, Cui H, Peng X, Fang J, Zuo Z, Deng J and Luo Q. Effects of high dietary fluorine on erythrocytes and erythrocyte immune adherence function in broiler chickens. Biological trace element research. 2013; 155:247-252.

27. Deng Y, Cui H, Peng X, Fang J, Zuo Z, Deng J and Luo Q. High dietary fluorine alteration of serum cytokine and immunoglobulin in broilers. Fluoride. 2013; 46:118-127. 
28. Luo Q, Cui H, Peng X, Fang J, Zuo Z, Deng J, Liu J and Deng Y. Dietary high fluorine alters intestinal microbiota in broiler chickens. Biological Trace Element Research. 2016:1-9.

29. Luo Q, Cui H, Peng X, Fang J, Zuo Z, Deng J, Liu J and Deng Y. Intestinal IgA+ cell numbers as well as $\operatorname{IgA}$, $\mathrm{IgG}$, and IgM contents correlate with mucosal humoral immunity of broilers during supplementation with high fluorine in the diets. Biological trace element research. 2013; 154:62-72.

30. Luo Q, Cui H, Peng X, Fang J, Zuo Z, Liu J, Wu B, Wang $\mathrm{H}$, Deng Y and Huang J. Intestinal oxidative stress in broilers caused by high dietary fluorine. Fluoride. 2012; 45:349-356.

31. Luo Q, Cui H, Peng X, Fang J, Zuo Z, Deng J, Liu J and Deng Y. Suppressive effects of dietary high fluorine on the intestinal development in broilers. Biological trace element research. 2013; 156:153-165.

32. Luo Q, Cui H, Peng X, Fang J, Zuo Z, Liu J, Wu B and Deng Y. The association between cytokines and intestinal mucosal immunity among broilers fed on diets supplemented with fluorine. Biological trace element research. 2013; 152:212-218.

33. Liu Y, Guan Z, Gao Q and Pei J. Increased level of apoptosis in rat brains and SH-SY5Y cells exposed to excessive fluoride-a mechanism connected with activating JNK phosphorylation. Toxicology letters. 2011; 204:183-189.

34. Niu Q, Liu H, Guan Z, Zeng Q, Guo S, He P, Guo L, Gao $\mathrm{P}, \mathrm{Xu} \mathrm{B}$ and $\mathrm{Xu} \mathrm{Z}$. The effect of c-Fos demethylation on sodium fluoride-induced apoptosis in L-02 cells. Biological trace element research. 2012; 149:102-109.

35. Zhao Y, Huo M, Liu Y, Xie Y, Wang J, Li Y and Wanga J. Effects of fluoride on the expression of BMP-2 and SMAD1 in rat osteoblasts in vitro. Fluoride. 2016; 49:13-22.

36. Zhang M, Wang A, Xia T and He P. Effects of fluoride on DNA damage, S-phase cell-cycle arrest and the expression of NF- $\kappa \mathrm{B}$ in primary cultured rat hippocampal neurons. Toxicology Letters. 2008; 179:1-5.

37. Wang Z-h, Li X-1, Yang Z-q and Xu M. Fluorine-induced apoptosis and lipid peroxidation in human hair follicles in vitro. Biological trace element research. 2010; 137:280-288.

38. Peng W, Zhang J, Lei M and Xua S. The effect of fluoride on the immune functions of cultured splenic T lymphocytes in male mice. Fluoride. 2016; 49:56-70.

39. Sojka B, Kuricova M, Liskova A, Bartusova M, Banski M, Misiewicz J, Dusinska M, Horvathova M, Jahnova E and
Ilavska S. Hydrophobic sodium fluoride-based nanocrystals doped with lanthanide ions: assessment of in vitro toxicity to human blood lymphocytes and phagocytes. Journal of Applied Toxicology. 2014; 34:1220-1225.

40. Mebius RE and Kraal G. Structure and function of the spleen. Nature Reviews Immunology. 2005; 5:606-616.

41. Cesta MF. Normal structure, function, and histology of the spleen. Toxicologic pathology. 2006; 34:455-465.

42. Koretzky GA. Multiple roles of CD4 and CD8 in T cell activation. The journal of immunology. 2010; 185:2643-2644.

43. Chabalgoity JA, Baz A, Rial A and Grille S. The relevance of cytokines for development of protective immunity and rational design of vaccines. Cytokine \& growth factor reviews. 2007; 18:195-207.

44. Guo H, Cui H, Peng X, Fang J, Zuo Z, Deng J, Wang X, Wu B and Chen K. Dietary NiCl2 causes G2/M cell cycle arrest in the broiler's kidney. Oncotarget. 2015; 6:35964-35977. doi: 10.18632/oncotarget.5934.

45. Dinarello CA. Historical insights into cytokines. European journal of immunology. 2007; 37:S34-S45.

46. Bao Y, Han Y, Chen Z, Xu S and Cao X. IFN- $\alpha$-producing PDCA-1+ Siglec-H- B cells mediate innate immune defense by activating NK cells. European journal of immunology. 2011; 41:657-668.

47. Bonilla FA and Oettgen HC. Adaptive immunity. Journal of Allergy and Clinical Immunology. 2010; 125:S33-S40.

48. Podder S, Chattopadhyay A, Bhattacharya S and Ranjan Ray M. Histopathology and cell cycle alteration in the spleen of mice from low and high doses of sodium fluoride. Fluoride. 2010; 43:237.

49. Lukas J, Herzinger T, Hansen K, Moroni MC, Resnitzky D, Helin K, Reed SI and Bartek J. Cyclin E-induced S phase without activation of the $\mathrm{pRb} / \mathrm{E} 2 \mathrm{~F}$ pathway. Genes \& Development. 1997; 11:1479-1492.

50. Sanchez I and Dynlacht BD. New insights into cyclins, CDKs, and cell cycle control. Seminars in cell \& developmental biology. 2005; 16:311-321.

51. Ngoc TDN, Son Y-O, Lim S-S, Shi X, Kim J-G, Heo JS, Choe Y, Jeon Y-M and Lee J-C. Sodium fluoride induces apoptosis in mouse embryonic stem cells through ROSdependent and caspase-and JNK-mediated pathways. Toxicology and applied pharmacology. 2012; 259:329-337. 